\title{
Two mechanisms of aquatic and terrestrial habitat change along an Alaskan Arctic coastline
}

\author{
Christopher D. Arp • Benjamin M. Jones • \\ Joel A. Schmutz $\cdot$ Frank E. Urban $\cdot$ M. Torre Jorgenson
}

Received: 29 October 2009 / Revised: 7 April 2010 / Accepted: 8 April 2010 / Published online: 27 April 2010

(C) The Author(s) 2010. This article is published with open access at Springerlink.com

\begin{abstract}
Arctic habitats at the interface between land and sea are particularly vulnerable to climate change. The northern Teshekpuk Lake Special Area (N-TLSA), a coastal plain ecosystem along the Beaufort Sea in northern Alaska, provides habitat for migratory waterbirds, caribou, and potentially, denning polar bears. The $60-\mathrm{km}$ coastline of N-TLSA is experiencing increasing rates of coastline erosion and storm surge flooding far inland resulting in lake drainage and conversion of freshwater lakes to estuaries. These physical mechanisms are affecting upland tundra as well. To better understand how these processes are affecting habitat, we analyzed long-term observational records coupled with recent short-term monitoring. Nearly the entire coastline has accelerating rates of erosion ranging from $6 \mathrm{~m} /$ year from 1955 to 1979 and most recently peaking at 17 m/year from 2007 to 2009 , yet an intensive monitoring site along a higher bluff (3-6 masl) suggested high interannual variability. The frequency and magnitude of storm events appears to be increasing along this coastline and these patterns correspond to a greater number of lake tapping and flooding events since 2000. For the entire $\mathrm{N}$-TLSA, we estimate that $6 \%$ of the landscape consists of salt-burned tundra, while $41 \%$ is prone to storm surge flooding. This offset may indicate the relative frequency of
\end{abstract}

C. D. Arp $(\varangle)$ B. M. Jones · J. A. Schmutz

Alaska Science Center, U.S. Geological Survey,

Anchorage, AK 99508-4664, USA

e-mail: carp@usgs.gov

F. E. Urban

Earth Surface Processes Team,

U.S. Geological Survey, Denver, CO 80225, USA

M. T. Jorgenson

ABR, Inc., Fairbanks, AK 99708, USA low-magnitude flood events along the coastal fringe. Monitoring of coastline lakes confirms that moderate westerly storms create extensive flooding, while easterly storms have negligible effects on lakes and low-lying tundra. This study of two interacting physical mechanisms, coastal erosion and storm surge flooding, provides an important example of the complexities and data needs for predicting habitat change and biological responses along Arctic land-ocean interfaces.

Keywords Arctic Coastal Plain - Alaska .

Coastal erosion · Storm surge flooding · Salt-burned tundra . Thermokarst lakes $\cdot$ Lake drainage

\section{Introduction}

Dramatic changes in climate, permafrost condition, and sea ice extent in the Arctic (Hinzman et al. 2005; RichterMenge et al. 2008) are having profound impacts on a number of biological populations (Post et al. 2009). Populations appear to be responding to large-scale forcings associated with a rapidly changing Arctic climate, yet the proximate factors causing shifts in abundance or distribution are often difficult to model and predict without a detailed understanding of the physical processes driving habitat change.

The Arctic is a biologically important region, providing essential habitat for a number of biological populations of current management interest, including black brant (Branta bernicla nigricans) (Bollinger and Derksen 1996; Flint et al. 2008), king eider (Somateria spectabilis) (Bentzen et al. 2008), caribou (Rangifer tarandus grantii) (Person et al. 2007), and polar bear (Ursus maritimus) (Fischbach et al. 2007; Smith et al. 2007). In northern Alaska, much of this habitat exists at the ocean-land interface where the 
hinterland is often characterized by lowland tundra, wetlands, and thermokarst lakes. The Teshekpuk Lake Special Area (TLSA), located about midway between Barrow and Prudhoe Bay, is recognized as one of the most important wildlife regions in northern Alaska and the Arctic. The northern portion of the TLSA (N-TLSA) provides essential molting habitat for black brant (Bollinger and Derksen 1996; Derksen et al. 1982), along with supporting significant numbers of breeding and molting snow geese (Chen caerulescens caerulescens), Canada geese (Branta hutchinsii), and greater white-fronted geese (Anser albifrons frontalis) (King and Hodges 1979). Long-term datasets suggest that these goose populations have shifted distribution during the last 30 years; whether this is in response to recent habitat change is uncertain (Flint et al. 2008). The Teshekpuk Lake caribou herd also utilizes this area for foraging during winter, where snowpacks are smaller and expose more vegetation, and for foraging and calf rearing during summer, where coastal winds and low temperatures create a refuge from mosquitoes (Person et al. 2007). Beaufort Sea polar bear populations are anticipated to decline in response to diminished sea ice extent (Durner et al. 2009) and evidence suggests a shift from pack ice denning sites to shoreline dens among Beaufort Sea populations (Fischbach et al. 2007), including known dens adjacent to the N-TLSA on nearshore islands (Smith et al. 2007). The N-TLSA is currently devoid of any significant human presence and development, making this coastline an excellent location to monitor and analyze how habitat and biological communities respond to a rapidly changing Arctic climate at the ocean-land interface.

The outer Arctic Coastal Plain (ACP) of northern Alaska is well within the continuous permafrost zone. For the N-TLSA study area, sediments are fine-grained and the permafrost tends to be very ice-rich, which has resulted in a matrix of large-scale, thermokarst features (thermokarst lakes and drained lake basins) across the landscape (Brown 1968; Sellmann et al. 1975), creating a heterogeneous land surface that provides many different habitat types. Along the ocean-land interface, these habitat types are vulnerable to change through two main mechanisms, coastal erosion and storm surge flooding. Due to the configuration of the N-TLSA coastline, these disturbance agents are manifested to different degrees across space and time (Jones et al. 2009b).

The N-TLSA has historically experienced some of the highest rates of coastal erosion worldwide (Jorgenson and Brown 2005; Reimnitz et al. 1988), and recent studies indicate that these historically high shoreline retreat rates are increasing (Jones et al. 2009b). This change is not only converting land to sea but also changing the configuration of the N-TLSA coastline, including breaching of lakes and higher rates of beach building along some segments (Jones et al. 2008, 2009b; Mars and Houseknecht 2007). Unresolved questions about this erosion pattern relate to whether this is a trend toward accelerating rates or only an episode of higher rates related to a period of rapid sea ice loss (Jones et al. 2009d). Summer and fall storms acting on the coastline, and their frequency, magnitude, and direction, factor into how the coastline is changing (Lynch et al. 2004; Manson et al. 2005). These storm components not only drive coastal erosion but also dictate how storm surges develop that flood inland, salinizing lakes and impacting tundra habitat (Flint et al. 2008; Reimnitz and Maurer 1979). Salt-burned tundra, as indicated by varying degrees of necrosis, can result from such storm surges (Taylor 1981). However, the types of vegetation susceptible to storm surges and persistence of those affects are less certain (Person and Ruess 2003; Reimnitz and Maurer 1979; Ruz et al. 1992). A storm in 1970 generated a 3-m storm surge, considered a 100-year event, inundating some regions of the ACP a distance of 5-km inland, as evidenced by woodlines and salt-burned tundra (Reimnitz and Maurer 1979). However, given the interaction among sea ice extent, fetch, wind stress, and wave action (Lynch et al. 2004) coupled with a sharply declining sea ice extent (Stroeve et al. 2007), the effectiveness of moderate winds in generating storm surges and eroding the coastline may be increasing (Atkinson 2005; Jones et al. 2009b). These two dominant mechanisms - coastal erosion and storm surge floodingalso interact with changes occurring within the terrestrial permafrost environment of the ACP (Lawrence et al. 2008) such as progressive lake expansion due to thermokarst erosion (Arp et al. unpublished data) and potentially lowering of land levels due to deflation of ice-rich permafrost (Couture and Pollard 2007).

Here, we analyze the historical records documenting these processes and bring more recent and detailed observations to bear on when and how these processes operate and impact coastline habitats. Such coupling of long-term observation-based studies with shorter-term process-based studies provides a reasonable and often the only realistic approach for evaluating habitat responses to physical forcings like climate warming in settings like the N-TLSA and other Arctic coastal environments. Additionally, the low elevation and northerly exposure of the N-TLSA coastline, coupled with a lack of riverine sediment delivery and barrier islands, provide an ideal setting where we would expect to see the earliest and most rapid coastline responses to climate change (Jones et al. 2009b). Thus, studies to understand the mechanism by which climate change impacts Arctic coastlines, habitat, and biological communities conducted now in the N-TLSA may help develop models and support future management decisions about other Arctic coastal areas where responses to climate change are less well manifested. 


\section{Study area}

The TLSA is approximately $7,080 \mathrm{~km}^{2}$ and part of the National Petroleum Reserve-Alaska (NPR-A) in northern Alaska. Our study area lies along the $60-\mathrm{km}$ segment of north-facing coastline between Drew Point and Cape Halkett (Fig. 1). The study area is wholly contained within the outer ACP, an emergent part of the continental shelf (Carson and Hussey 1962) with 7-8 marine transgressions since the late Cenozoic (Brigham-Grette and Carter 1992; Hopkins 1967). Land surfaces are thought to have been relatively stable since the Simpsonian transgression 78-58 thousand years ago, when sea levels were 7-10 m higher than present (Brigham-Grette and Hopkins 1995). However, recent evidence indicates past continental glaciation of the region (Jorgenson and Shur 2008). Surface elevation ranges from sea-level up to $10 \mathrm{~m}$; with most surfaces ranging from 1 to $3 \mathrm{~m}$ along the eastern portion to $3-6 \mathrm{~m}$ along the western portion of the N-TLSA (Fig. 1). Tidal range in this portion of the Beaufort Sea is low, 0.4 m (NOAA Prudhoe Bay Tide Gage), but the spatial and temporal variation is not well documented for our study coastline (Jones et al. 2009d). The surficial geology is characterized by organicrich, glacio-marine silty sediments cemented as permafrost. The permafrost extent is continuous and reaches depths up to $400 \mathrm{~m}$ with high ice content of $20 \%$ in the upper 10-20 $\mathrm{m}$ and $70 \%$ in the upper 1-2 $\mathrm{m}$ (Brown 1968; Sellmann et al. 1975). Degradation of this ice-rich permafrost has resulted in the formation of numerous oriented thermokarst lakes (Carson and Hussey 1962) and drained thaw lake basins (DTLBs), many of which originated 5,500-2,000 BP (Hinkel et al. 2003).
The N-TLSA is part of the Arctic Coastal Plain Lake District, the second largest major lake district in Alaska at $56,000 \mathrm{~km}^{2}$ with a lake-area extent of $17 \%$ and over 50 thousand lakes $>1$ ha (Arp and Jones 2009). The TLSA has $>25 \%$ lake-area extent, not including Teshekpuk Lake, and 500 lakes $>1$ ha, including many larger lakes that are uniformly oriented NNW to SSE at $5-15^{\circ} \mathrm{W}$ of $\mathrm{N}$ (Carson and Hussey 1962) (Fig. 1). Most lakes are less than $3 \mathrm{~m}$ deep, with many shallower than maximum ice thickness $(<2 \mathrm{~m})$ such that they freeze completely to the bed, lack thaw bulb taliks, and thaw at differing rates than lakes with perennially unfrozen sediments (Jones et al. 2009a). These lakes range from freshwater with very low ionic strength to brackish depending on elevation, surface connectivity to the sea, and drainage area (Arp et al. unpublished data).

In 1977, the N-TLSA was give special protected status in part because it provides important molting habitat for black brant (Fig. 2a), along with three other goose species and has a very high abundance of other waterbirds (Bollinger and Derksen 1996; Derksen et al. 1982). The TLSA also has protected status because it provides important calving and rearing ground for the Teshekpuk Lake caribou herd (Fig. 2b) (Person et al. 2007). This area was traditionally used for subsistence hunting and fishing by Native peoples of the region. Accounts suggest that molting geese, particularly black brant, had been harvested by the hundreds in the TLSA during their flightless period as recently as the 1950s (Silva 1985, unpublished report). The most common vegetation in the N-TLSA is moist and wet sedge meadow tundra; both types are dominantly composed of Carex aquatilis and
Fig. 1 Study area map showing a the study coastline of the Teshekpuk Lake Special Area with numbered study lakes and major landmarks indicated and b the regional coastline of the Alaskan Arctic Coastal Plain with the domain of the study coastline and major landmarks indicated

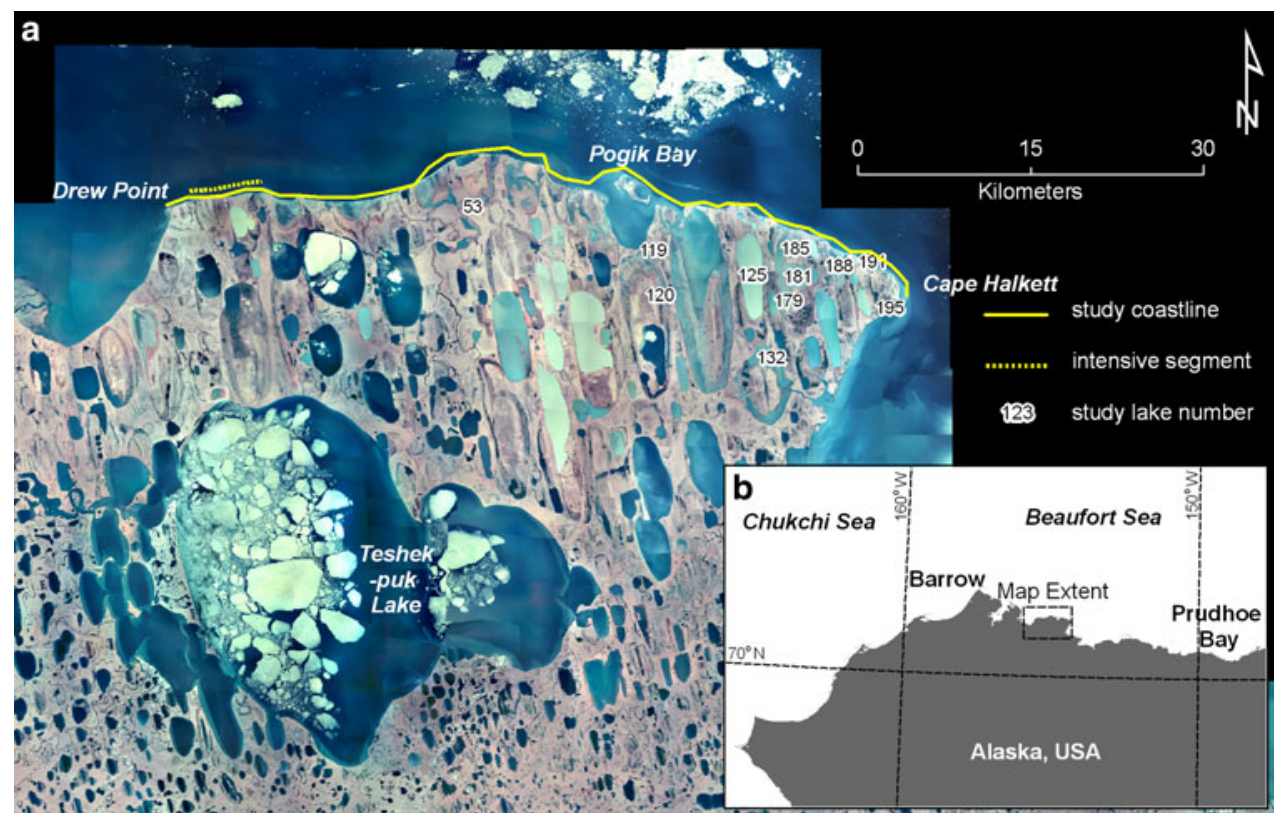


Fig. 2 Examples of major wildlife species and rapidly changing habitats in the Teshekpuk Lake Special Area including a a flock of black brant during the molt on a large oriented thaw lake, $\mathbf{b}$ two members of the Teshekpuk Lake caribou herd grazing along the coastline in mid-July when sea ice is often still visible, $\mathbf{c}$ a collapsed permafrost block and developing thermo-erosional niche near Drew Point, and d abrupt transition between saltburned and unaffected lowcentered polygon tundra near Pogik Bay (photo A was taken by Garrett Vyn and other are USGS photographs)

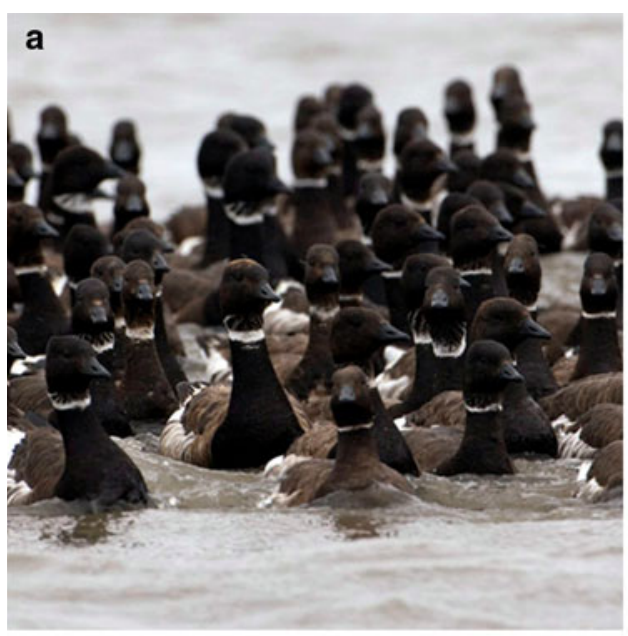

b

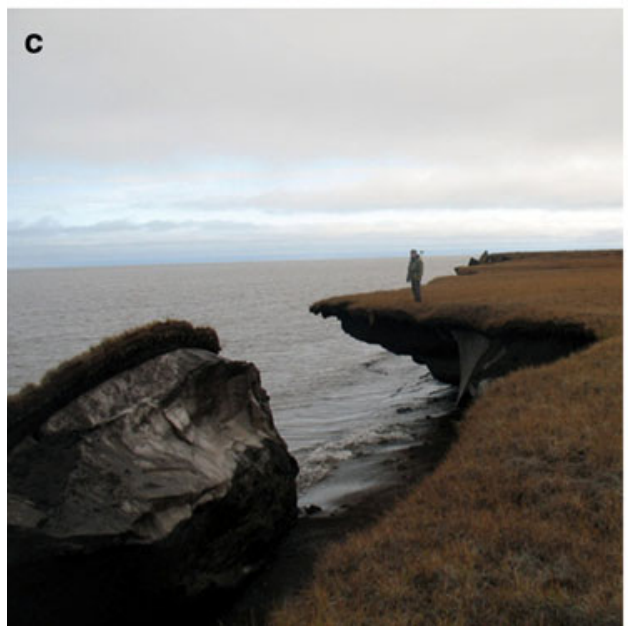

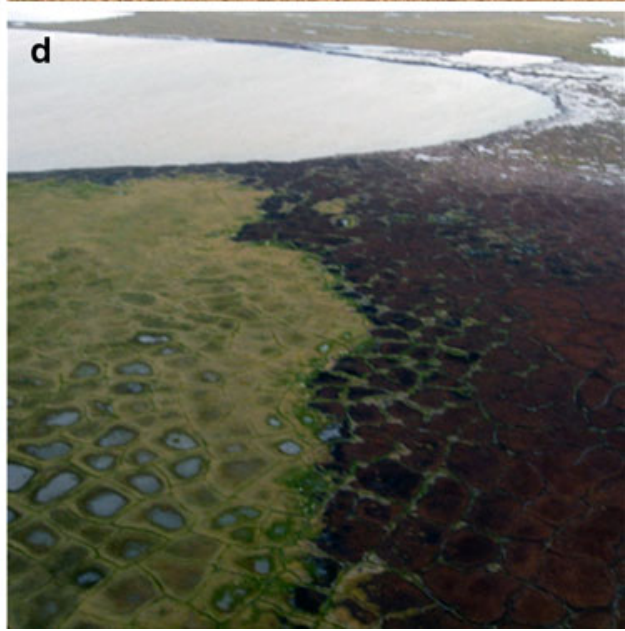

Eriophorum sp. with herbaceous and bryophyte understory cover (Markon and Derksen 1994). Lake shoreline plants include Arctophila fulva, E. angustifolium, and C. aquatilis in littoral and flooded zones and Sphagnum sp. and brown mosses on low-relief shoreline shelves, the latter being preferred loafing habitat for geese. Halophytic sedge-grass meadow tundra occurs in low areas, near the coastline and meso- to poly-haline lakeshores, composed primarily of C. subspathacea and Puccinellia phryganodes (Markon and Derksen 1994), and is often preferred grazing for black brant (Flint et al. 2008, Taylor 1981). The immediate context for the investigations presented here focused on the prediction of future changes in wildlife habitat, specifically for molting black brant (Fig. 2a) that use large thermokarst lakes along the coast. Thus, the primary goal of this study is to understand the long-term effects and underlying processes that modify lake and shoreline physical habitat, habitat quality in terms of water and soil salinity and associated vegetation, (Fig. 2d), and changes in coastline position due to erosion (Fig. 2c).

\section{Methods}

Remote sensing and analysis of erosion and habitat change

We compiled a number of datasets with explicit geographic information regarding associated habitat characteristics and landscape change in a geographic information system (GIS) framework. This consisted of both aerial and satellite imagery, past land-cover classifications for the region, ground observations and field data, and digital elevation models (DEMs). Analysis of a wide array of geographic datasets allowed us to identify past and present coastline positions, lake drainage and flooding events, vegetation classes and salt-burned tundra, particularly with respect to how they have been altered during the last half-century.

Delineations of coastline positions along a $60-\mathrm{km}$ segment of the N-TLSA coast between Drew Point and Cape Halkett (Fig. 1) was accomplished using imagery from (1) 15 August 1955 (1:55,000 scale, Band W aerial photography), (2) 19 July 1979 (1:63,360 scale, CIR aerial photography), (3) 18 July 2002 (1:40,000 scale, CIR aerial 
photography), (4) 17 July 2007 (1:50,000 scale, true-color aerial photography) in Jones et al. (2009b) and updated with (5) 2009 data using a combination of Ikonos ${ }^{\circledR}$ and Worldview ${ }^{\circledR}$ high-resolution satellite imagery $(0.5-1.0 \mathrm{~m}$ resolution) acquired between 14 and 20 July 2009. Geo-referencing and ocean-land interface identification follow methods in Jones et al. (2008) and accuracy assessment follow methods in Jones et al. (2009b). Further, along a 0.7-km subsegment near Drew Point (Fig. 1), additional coastline positions were acquired by walking along the breaking edge of the coastal bluff with a differential GPS (DGPS) on 5 June 2008, 28 August 2008, and 23 August 2009 and compared to $30-\mathrm{cm}$ aerial photography acquired on 16 July 2007 and 4 September 2007 to better understand seasonal and interannual variability in erosion. Change in coastline positions or coastal erosion rates was analyzed using U.S. Geological Survey, Digital Shoreline Analysis System (DSAS) (Theiler et al. 2005) at 100-m increments for each time period between Drew Point and Cape Halkett and at 5-m increments for the intensive survey site located near Drew Point (Fig. 1).

The timing of lake drainage by coastal erosion (tapping), lake flooding by coastal erosion when lake basins were at or below sea level, and major flooding by storm surge inundation was analyzed using a combination of coastline positions from the previous analysis and observed shifts in the surface connectivity to the coast by channels or other lowlands. Additionally, to further resolve the timing of these lake change events, we analyzed Landsat imagery from 1973 to present, declassified satellite imagery from the 1960s and 1970s, and synthetic aperture radar (SAR), which can detect differences between fresh- and brackishwaters below ice (Mellor 1982), acquired from the Alaska Satellite Facility post-1996 (Eicken et al. 2006).

Mapping and analysis of landcover vegetation and habitat classes used a combination of previously analyzed Systeme Pour l' Observation de la Terre (SPOT) data from 6 to 8 July 1986 (Markon and Derksen 1994), an interferometric SAR-derived DEM from 2002, and an Advanced Spaceborne Thermal Emission and Reflection Radiometer (ASTER) derived classification of salt-burned tundra. These geospatial datasets were used in a GIS framework to identify changes in habitat due to land lost to coastal erosion, by varying storm surge floods, and resulting from saltwater flooding and salt-burned tundra.

Meteorological record and storm analysis

The longest and closest meteorological records representing N-TLSA conditions are from Barrow, AK, approximately $100 \mathrm{~km}$ to the west. We used 6-h interval wind velocity and direction data from this site to evaluate the frequency and magnitude of storms potentially impacting this area since 1955. Storms were defined as events exceeding wind velocities of $10 \mathrm{~m} / \mathrm{s}$ for $>12 \mathrm{~h}$ and were considered effective storms (Manson et al. 2005) on the TLSA if they primarily acted on the coast from a west-northwest $\left(270^{\circ}\right)$ to east-northeast direction $\left(90^{\circ}\right)$ between July and October when shorefast ice was usually absent. Storm magnitudes were summarized by storm power value, which combines velocity with duration (Atkinson 2005). A more proximate meteorological station at Drew Point in the N-TLSA (Fig. 1) was compared to Barrow records for 2005-2008. Storms impacting this area were further divided as west $\left(270-360^{\circ}\right)$ or east $\left(0-90^{\circ}\right)$, as these opposing wind directions are known to differentially influence sea level and surge magnitude along the Beaufort Sea coast (Reimnitz and Maurer 1979).

\section{Lake and ocean monitoring}

Several key lakes and near-shore ocean locations were instrumented with pressure transducers that record water levels and water temperature. These instruments were installed in the summer of 2007 at Lake 195 near the shoreline and through the ice at lake centers in April 2008 at Lakes 53, 132, and 190 and held to the bottom with a sand bag attached to line and buoy. To measure water depth, readings from pressure transducers were corrected by local atmospheric pressure measurements at either Cape Halkett or Teshekpuk Lake. All lake instruments were recorded at hourly intervals and were checked against independent field measurements of depth. Lake salinity levels measured by specific conductance (SC) were recorded at $>30$ lakes in early September 2007 and/or late August 2008. Additionally, USGS water quality surveys including measurements of SC were also conducted at a subset of these lakes in 1977 and from 2004 to 2006 (USGS-NWIS). Offshore sensors were installed at Elson Lagoon, $\sim 80 \mathrm{~km}$ west of N-TLSA, and Barter Island, $\sim 300 \mathrm{~km}$ east of N-TLSA, in 2005 and more recently at Cape Halkett (Fig. 1) in 2009 to monitor sea levels and nearshore sea surface temperatures (SST). Soil temperature of near-surface permafrost was measured with thermistors placed at $1 \mathrm{~m}$ depth near the Drew Point weather station since 1998 and also near Cape Halkett from March to August 2009.

\section{Results and discussion}

Coastal erosion: long-term patterns and short-term processes

The TLSA is known to have some of the highest rates of coastline erosion in the Arctic (Jorgenson and Brown 2005; Reimnitz et al. 1988) with the most recent measurements 
for the entire north-facing coastline of $13.6 \mathrm{~m} /$ year between 2002 and 2007 compared to $8.7 \mathrm{~m} /$ year between 1979 and 2002 and $6.8 \mathrm{~m} /$ year between 1955 and 1979 (Jones et al. 2009b). We have updated the recent erosional patterns of this coastal segment by analyzing high-resolution satellite imagery acquired 14-20 July 2009. This comparison of coastline positions with the 2007 imagery indicates a mean annual erosion rate of $17.1 \pm 3.1 \mathrm{~m} /$ year, therefore the increase in erosion rates documented between 2002 and 2007 has been sustained. We were also able to assess seasonal erosional patterns for a $750-\mathrm{m}$ stretch of coast near Drew Point (Figs. 1, 3) in the context of driving processes. At this site, the bluff-face is relatively high, typically $>3 \mathrm{~m}$, thus representing a segment of coastline where we expected few storm-surge floods and only unidirectional loss of coastline habitat.

This more recent and higher temporal resolution analysis of land loss captures some interesting patterns of seasonal and inter-annual variability which allow us to compare environmental conditions during periods with differences in erosional magnitude (Table 1). During 5 nearly equal time periods when the coastline was exposed to the open ocean, erosional loss ranged from $2.1 \mathrm{~m}$ in late summer and fall 2008 to $12.2 \mathrm{~m}$ in the previous summer and fall 2007 (Table 1). The early summer period in 2009 also had high erosion losses. We found little correlation with higher temporal resolution measurements to storm events, SST, and coastline permafrost temperatures, factors that are known to regulate thermo-mechanical niche erosion along the Beaufort Sea coast (Jones et al. 2009b, Reimnitz et al. 1988). Particularly interesting is the lack of coherence between storm events and erosion rates with the single westerly storm corresponding to only moderate amounts of erosion and high erosion rates occurring in 2009 in the absence of any effective storm event. It is understood, however, that the westerly storm in 2008 produced a regional cooling affect on air and surface-waters and that 2007 had abnormally high air and surface water temperatures due to a persistent high pressure system (Arp et al. in press, Jones et al. 2009c). This sharp interannual climate variation was not captured in the mean SST and soil temperature for these periods; still we suspect that these conditions played a role in controlling the amount of thermal erosion of ice-rich bluffs. Currently, efforts are underway to improve data collection in the N-TLSA to better understand the processes driving this high degree of interannual variation in erosion rates observed in this study (Jones et al. 2009d).

Fig. 3 An example of coastline erosion near Point Drew showing a a Worldview $2.5-\mathrm{m}$ resolution satellite image acquired in 2008 with past coastline positions and associated erosion rates indicated. The nearshore pond shown orthogonally in (a) is shown obliquely in 2008 b before and in 2009 c after being tapped and drained
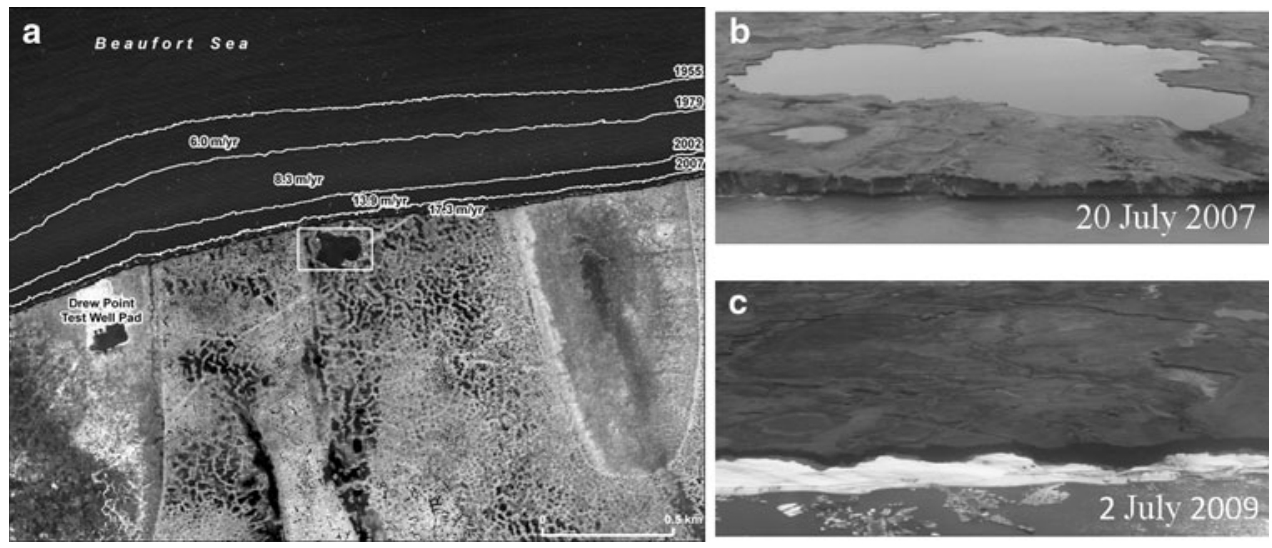

Table 1 Short time-period ( $\sim 2$ months during open-water season) erosion loss for a $0.7-\mathrm{km}$ segment measured at 138 intervals of coastline near Drew Point compared to the occurrence and direction of storms (toward the coastline and exceeding $10 \mathrm{~m} / \mathrm{s}$ wind velocities for
$>12 \mathrm{~h}$ measured at Drew Point), sea surface temperature (Elson Lagoon/Barter Island/Cape Halkett), and coastline permafrost temperature (100-cm depth at Drew Point)

\begin{tabular}{lclll}
\hline Period & $\begin{array}{l}\text { Erosion } \\
(\mathrm{m}, \text { mean } \pm 1 \mathrm{SE})\end{array}$ & $\begin{array}{l}\text { Number } \\
\text { of storms }\end{array}$ & $\begin{array}{l}\text { Mean sea surface } \\
\text { temperature }\left({ }^{\circ} \mathrm{C}\right)\end{array}$ & $\begin{array}{l}\text { Mean soil } \\
\text { temperature }\left({ }^{\circ} \mathrm{C}\right)\end{array}$ \\
\hline 17 Jul 2007-4 Sep 2007 & $4.6 \pm 0.3$ & 0 & $7.6 /-/-$ & -2.7 \\
4 Sep 2007-5 Jun 2008 & $12.2 \pm 0.3$ & 1 -East & $-/ 1.3 /-$ & -2.0 \\
5 Jun 2008-28 Aug 2008 & $8.3 \pm 0.3$ & 1 -West & $-/-/-$ & -2.3 \\
28 Aug 2008-1 Jul 2009 & $2.1 \pm 0.3$ & 1 -East & $-/-/-$ & -1.6 \\
1 Jul 2009-23 Aug 2009 & $11.9 \pm 0.4$ & 0 & $-/-/ 6.0$ & -2.4
\end{tabular}

All driving variables are summarized only for the assumed open-water season of July to October 
Storms: long-term patterns and short-term responses

Coastal storms are known to have a profound effect on coastal erosion and can generate storm surge flooding during certain conditions (Manson et al. 2005). Longshore currents along the Beaufort Sea coast are consistently from the east (Walker 1985) such that westerly storms raise sea levels while easterly storms lower sea levels (Reimnitz and Maurer 1979; Reimnitz et al. 1988). Sea ice typically is absent from the coastline from July through September, but this may vary greatly from year to year and in 2007 sea ice reached a record minimum extent (Stroeve et al. 2007). Thus, the effectiveness of storms is not only determined by duration and magnitude, but also direction and timing. These processes coupled with sea ice extent interact to govern how effective storms are upon on coastline habitats through both flooding and erosion (Lynch et al. 2004).

Analysis of records from Barrow, AK in our study, along with more detailed analysis by Lynch et al. (2003), indicates both an increase in the frequency and magnitude of effective storms (Fig. 5). It appears, however, that storm severity may vary over relatively short distances along the ACP coastline. A comparison between the Barrow meteorological data and a short-term dataset from Drew Point (2005-2009) indicates that storms impacting the TLSA may not reach the same magnitude of storms recorded in Barrow (Fig. 5); however, this may also be due to differences in the height of the anemometer above the ground surface. Whether or not this relationship holds over longer time periods, it is notable that from 1971 to 1981 there were a low number and magnitude of storms, particularly westerly storms with only a low intensity storm in late October 1976. Prior to this low storm period, there was a major westerly storm around 13 September 1970 according to analysis by Reimnitz and Maurer (1979), which suggested that this was a 100-year storm event and produced a substantial storm surge exceeding 3 masl throughout much of the western and central Beaufort Sea coastline. Our analysis from Barrow, however, places this westerly event as relatively minor, further underscoring the variability in storm system behavior along the ACP coastline. Major storms impacted Barrow in 1963 and 2000 (Lynch et al. 2003) and it is uncertain to what degree these impacted the TLSA, although we note a number of lake flooding events in 2000 (Fig. 4). Another lull in westerly storms happened recently, starting in 2005 with only one storm occurring around 31 July 2008. The same period had seven easterly storms recorded at Barrow, yet only two were recorded in the TLSA at Drew Point (Fig. 5). These comparisons underscore the need for local monitoring networks to be established and maintained in areas of long-term research interest, such as the TLSA.

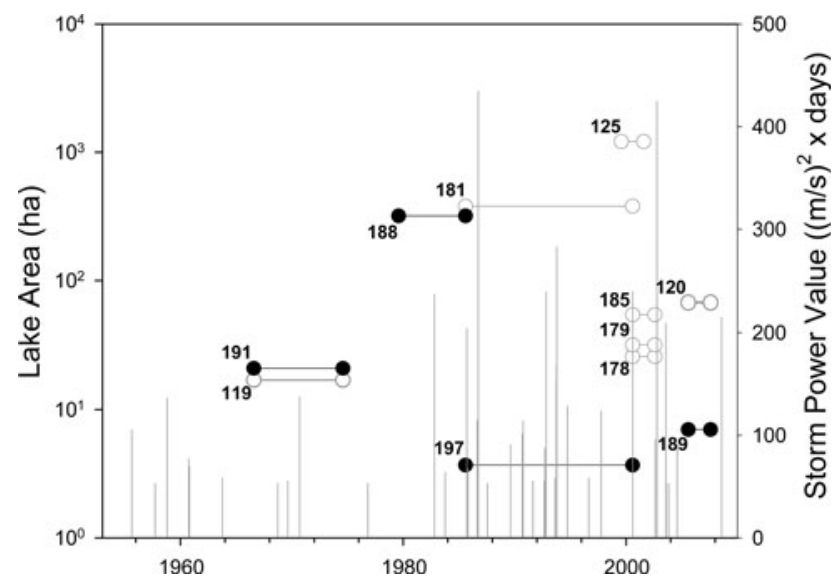

Fig. 4 Chronology of lakes breached by coastal erosion (closed circle with black line) and salinized by a combination of storm surge flooding and newly opened flood pathways by coastal erosion (open circles with gray line) identified by aerial photography, Landsat, and SAR imagery (numbers indicate each lake). Large westerly storms recorded at Barrow are shown as bars with storm power value on the right $y$-axis
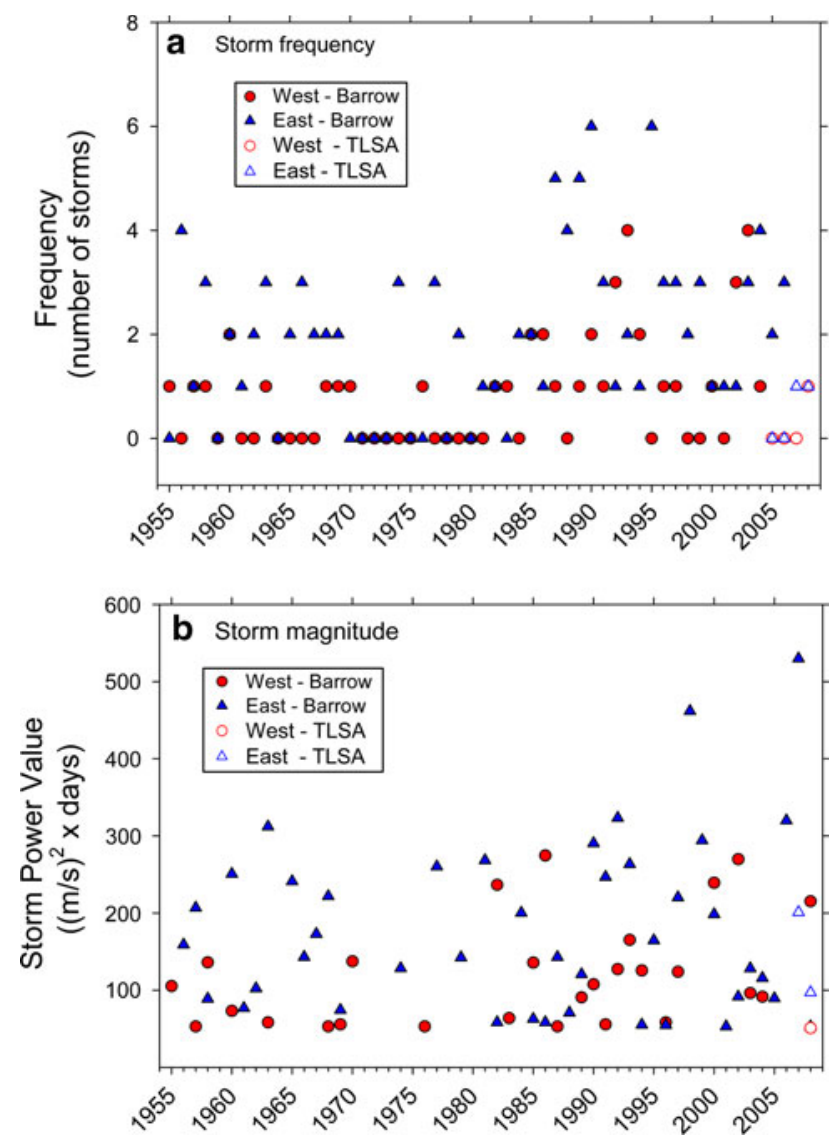

Fig. 5 Analysis of the frequency (a) and magnitude (b) of west versus east storms occurring in July to October since 1955 in Barrow and since 2005 in the TLSA

The role of easterly versus westerly winds on storm surge magnitude and impact to lakes was best described by comparing two storms in 2008-the westerly storm on 31 
July and an easterly storm on 10 October (Fig. 6). These events were of similar duration, 12 and $18 \mathrm{~h}$, respectively, and mean wind velocity, 10.1 and $11.4 \mathrm{~m} / \mathrm{s}$, respectively, yet had very different impacts on responses of four coastal lakes (Fig. 6). After the westerly storm, the low-lying lakes 53 and 132 with direct sea connectivity through outlet streams, peaked at 0.7 and $0.5 \mathrm{~m}$, respectively, above mean lake levels of 0.2 masl. After the easterly storm, however, Lake 53 levels increased by only $0.2 \mathrm{~m}$ and there was no discernable response at Lake 132. The lack of response, at these very low elevation lakes during the easterly storm event, emphasizes the importance of storm direction in controlling regional sea levels in the Beaufort Sea to a much greater extent than angle of wave attack (Reimnitz and Maurer 1979). Tidal flux in this portion of the Beaufort Sea is low, $40 \mathrm{~cm}$ (NOAA Prudhoe Bay Tide Gage) and this signal can be observed in our gaging data at Lake 132 during non-storm periods. Lakes 190 and 195 are at slightly higher elevation (>1 masl) without direct sea connectivity, but occur $<0.5 \mathrm{~km}$ from coastlines facing north to east and east to south, respectively (Fig. 1). Little to no response was recorded at either lake beside increased seiche; indicating that the storm surge for both events was $<1$ masl (Fig. 6). The lower-lying lakes that were impacted by the westerly storm actually are located much farther inland, but had well-defined surface connectivity to the coast. Such responses emphasize the need for high-resolution topographic data for these coastal environments, as well as local meteorological data and other environmental monitoring. Analysis of these events helps us place the longer-term record from Barrow into an appropriate context in terms of effects on the TLSA coastline and storm surges inland. These events likely play a consequential role in controlling both terrestrial and aquatic habitat and food webs, along with potentially creating direct disturbances to wildlife populations during short and dynamic Arctic summers.

Impacts to habitat from coastal erosion and storm surge flooding

\section{Terrestrial impacts}

Not only is the conversion of land to sea a dramatic change, but consideration of the proportion of various tundra types lost to coastal erosion is necessary from a habitat perspective (Table 2). Moss-peat shoreline and halophytic vegetation, types strongly preferred by black brant (Bollinger and Derksen 1996; Flint et al. 2008), comprised 0.1 and 1.6\% of the landscape, respectively. Sedge meadow, heavily utilized forage by caribou during certain times of the year, comprised $24 \%$ of the landscape in the N-TLSA. Comparison of land loss due to erosion showed a proportionally higher loss of moss-peat shorelines, $6.1 \%$, and moist sedge
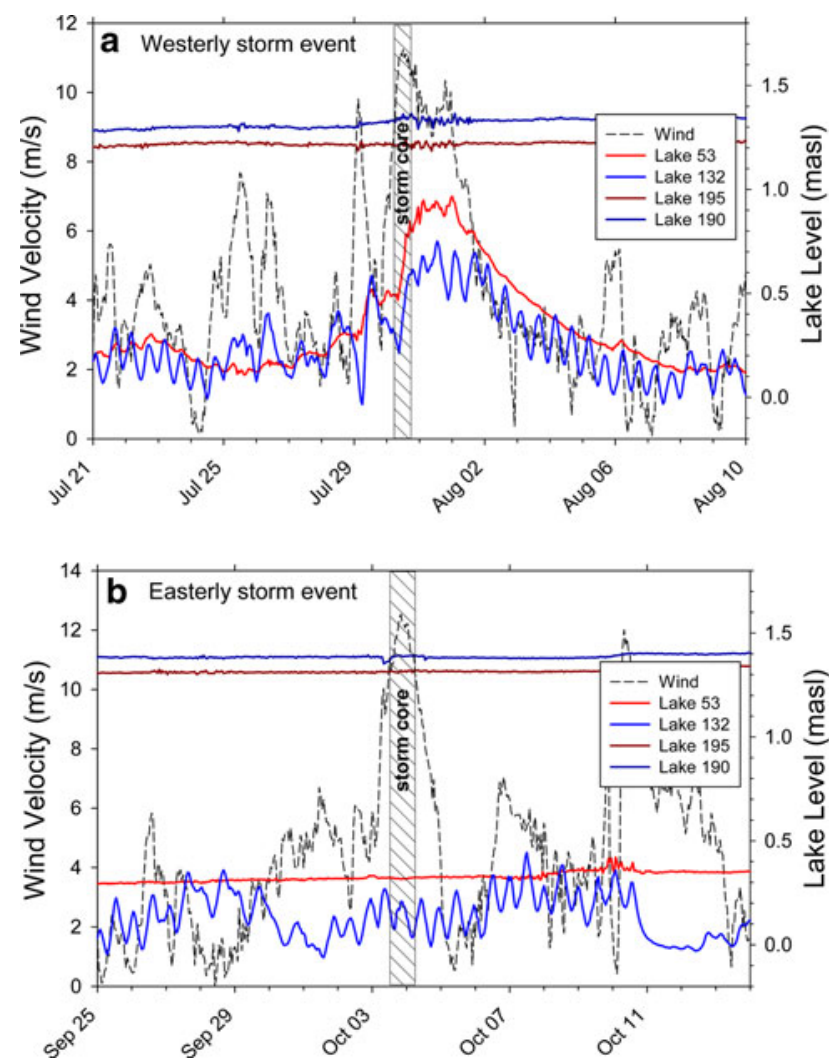

Fig. 6 Comparison of similar magnitude westerly (a) versus easterly storms (b) occurring in 2008 and their impact on water levels at four lakes located at differing elevations and shoreline orientations in the TLSA

meadow, $32 \%$, than the overall abundance of these tundra classes throughout the N-TLSA (Table 2). This mainly reflects differences in composition of coastal vegetation versus inland vegetation in the N-TLSA, but may also relate to how certain wildlife populations select forage and the resources adjacent to shoreline ecotones with very different microclimates and proximate habitats, such as the gradient from the Beaufort Sea coastline inland. Tundra vegetation types including moist grass/sedge meadow and dwarf shrub-graminoid classes were proportionally unchanged by erosional losses in the N-TLSA (Table 2).

\section{Aquatic impacts}

Recent erosion along Drew Point also resulted in the tapping and drainage of a pond located on a relatively high landscape position (Fig. 3). Such small waterbodies provide important habitat for certain shore-bird species, particularly during early summer when larger waterbodies retain ice cover. While it is difficult to document tapping of such small waterbodies with moderate resolution remotely sensed imagery, we were able to identify in delimited periods of time the tapping and drainage of many other larger lakes, which also provide essential habitat. For example, 
Table 2 Teshekpuk Lake tundra habitat classes from 1986 SPOT imagery and analysis (Markon and Derksen 1994) and proportions lost due to erosion, altered by storm-surge flooding, and prone to storm-surge flooding due to elevation and connectivity to the ocean

\begin{tabular}{lcccc}
\hline SPOT tundra classes & N-TLSA (\%) & $\begin{array}{l}\text { Erosion loss } \\
(1986-2008)(\%)\end{array}$ & $\begin{array}{l}\text { Salt-burned } \\
\text { tundra }(\%)\end{array}$ & $\begin{array}{l}\text { Flood-prone } \\
\text { areas }(\%)\end{array}$ \\
\hline Flooded & 6.7 & 2.5 & 11.3 & 7.1 \\
Wet sedge meadow & 15.4 & 5.3 & 22.3 & 13.8 \\
Moist sedge meadow & 24.0 & 32.0 & 27.8 & 16.9 \\
Moist grass/sedge meadow & 8.8 & 7.4 & 10.3 & 6.1 \\
Dwarf shrub-graminoid & 8.7 & 8.1 & 6.6 & 5.0 \\
Moss-peat shoreline & 0.1 & 6.2 & 0.0 & 2.4 \\
Sparsely vegetated & 1.4 & 6.1 & 4.1 & 2.4 \\
Unvegetated & 3.0 & 23.9 & 8.1 & 7.6 \\
Halophytic & 1.6 & 0.0 & 3.8 & 0.0 \\
Open-water & 30.2 & 8.4 & 5.8 & 38.8 \\
Total area $\left(\mathrm{km}^{2}\right)$ & 1,141 & 17 & 71 & 477 \\
\hline
\end{tabular}

black brant typically use larger oriented lakes during their molt, likely because they provide a refuge from predators coupled with ready access to shoreline grazing lawns (Bollinger and Derksen 1996, Flint et al. 2008). Several other lakes along this segment of coastline have been tapped and drained by coastal erosion (Fig. 4) — a common feature of the lake-rich coastal plains that provide a diverse habitat mosaic (Ruz et al. 1992). The role of such small or shallow lakes and wetlands in providing waterbird habitat may not be fully recognized in the ACP, but is likely shifting along these rapidly eroding coastlines with corresponding responses in avifauna and other wildlife populations. Remote sensing analysis indicated the timing of at least four lakes captured by coastal erosion since 1955, all of which were in the eastern portion of the TLSA (Fig. 4). Other accounts describe tapping of a very large lake in the TLSA, now Pogik Bay, somewhere between 1854 and 1919 (Jones et al. 2008), which emphasizes that this type of dramatic habitat conversion is not necessarily a new phenomena along this coastline, and has likely occurred throughout the Holocene. Still, with the documentation of much higher erosion rates that appear to correspond to low autumn sea ice extent (Jones et al. 2009b), it is reasonable to suppose that this type of habitat conversion is happening at a much faster rate with uncertain consequences to Arctic coastline biological communities (Flint et al. 2008).

Storm events, and their direction and timing, play a consequential role in shaping ACP coastlines (Ruz et al. 1992) and influence coastal vegetation communities and successional patterns (Taylor 1981). We defined the zone of potential saltwater flooding as areas $\leq 2.5$ masl with direct connections to the coastline. This maximum flood elevation was based on an estimate from Reimnitz and Maurer (1979) of the 100-year storm surge. This flood-prone zone covered $477 \mathrm{~km}^{2}$ or $41 \%$ of the N-TLSA where vegetation has been classified (Markon and Derksen, 1994), including much of the eastern low-lying tundra and lakes (Table 2; Fig. 7).
Areas of distinct salt-burned tundra, all were well within the maximum flooding zone and were $71 \mathrm{~km}^{2}$ in extent or $6 \%$ of the N-TLSA (Table 2; Fig. 7). Salt-burned tundra, likely due to salt-burn as indicated by necrosis (Taylor 1981), appeared most common in and around DTLBs being eroded into the sea and along the low gradient outlets of the Smith and Kogru Rivers and connected lakes. Most of the salt-burned tundra areas were formerly sedge meadow with varying moisture conditions (Table 2). Interestingly, our analysis identified little salt-affect on moss-peat shoreline types (brown mosses), though studies of storm surge flooding and salt-affects from the Yukon-Kuskokwim Delta suggest that bryophyte communities are most sensitive to saltwater, however, these are predominantly Sphagna at a differing landscape position (Jorgenson 2000, Jorgenson and Ely 2001). The rate at which vegetation recovers from salt-burn and how this may vary by plant community, soil type, and landscape position is uncertain, but warrants further study.

Lake water salinity, as measured by SC, within the flooding zone ranged from values near seawater of $49,000 \mu \mathrm{S} / \mathrm{cm}$ in Lake 188 and 41,000 $\mu \mathrm{S} / \mathrm{cm}$ in Lake 181 to as low as $230 \mu \mathrm{S} / \mathrm{cm}$ in Lake 106 (Fig. 7). Much of the variation in lake salinity can be explained by elevation, which influences susceptibility to flooding, and the degree to which freshwater inflow, flushes and dilutes intruded saltwater (Arp et al. unpublished data), the latter related to watershed area. Salinity of individual lakes may shift dramatically over time; for example, SC in Lake 188 increased by $>600 \%$ between 1977 and 2006. Hourly SC monitoring in lakes 181 and 132 in 2007 and 2008, however, shows strong day-to-day variation in lake salinization and freshening, related to tidal fluctuations, wind events (even weak ones), and rainfall-runoff patterns. Therefore, the exact timing of sample collection relative to storm surge inundation is critical, and long-term trends may not be safely interpreted unless short-term variability is accounted for. 
Fig. 7 A map showing portions of the TLSA subject to storm surge flooding (100-year storm, Reimnitz and Maurer 1979), ASTER mapped salt-burned tundra, and lake salinities (as specific conductance) of the N-TLSA

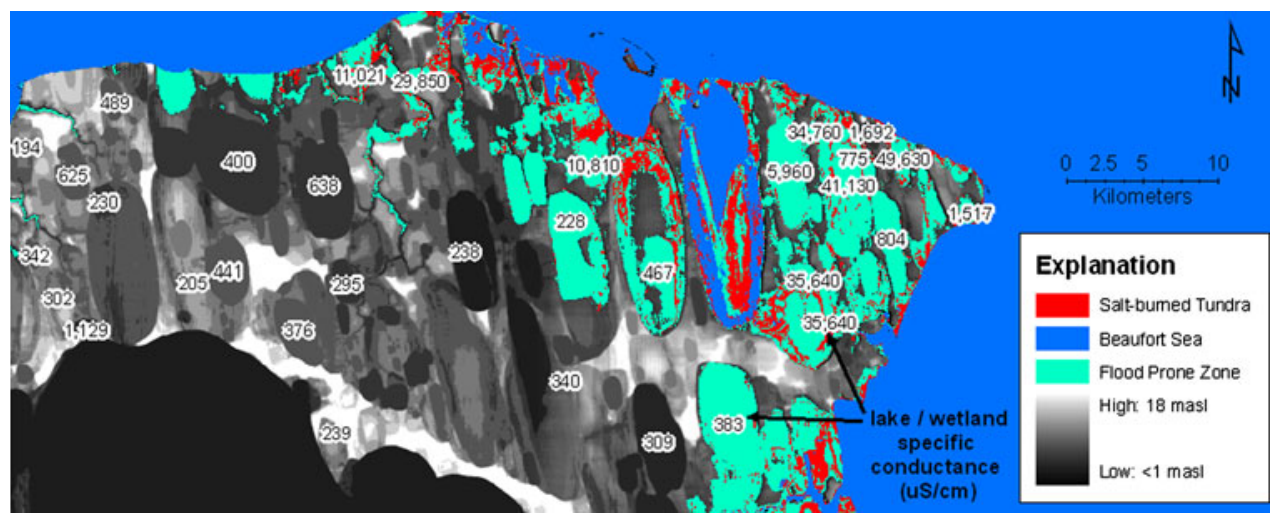

Our remote sensing analysis of lake flooding from storm surges helped bracket chronology of lake change events since 1955 and show at least seven lakes that fully or partly flooded with seawater (Fig. 4). The precision of this analysis increased during recent periods where we have more imagery available, including SAR. Still, this chronology suggests that recent flooding of Lake 125, a large oriented thaw lake known to support molting brant, occurred between 2000 and 2002, along with three other small lakes and ponds. The Barrow storm record shows very strong westerly storms in August 2000 (Lynch et al. 2003) and October 2002 (Fig. 5), which may have been responsible for flooding of these lakes. A large shallow lake, 181, within an oriented DTLB, also became open to frequent seawater flooding sometime between 1985 and 2000, during which time at least 10 westerly storms of magnitude and duration $>100$ storm power value were recorded (Figs. 4, 5).

Erosion likely has opened up pathways inland for storm surge flooding exacerbating its effect, particularly along portions of the ACP where microtopograhic relief often far exceeds regional elevation gradients. With such slight elevational gradients in a landscape with an increasingly dynamic surface, due to thermokarst processes (Jorgenson et al. 2006, Lawrence et al. 2008), land-deflation (Couture and Pollard 2007), and dynamic coastline (Jones et al. 2009b) as in the N-TLSA, even moderate estimates of sea level rise may greatly enhance these two mechanisms of Arctic coastal habitat change. Many other circumpolar coastal zones have similar attributes, also with very high lake densities, and may be similarly susceptible to the interacting mechanisms of erosion and flooding with uncertain consequences to aquatic and terrestrial habitat.

\section{Concluding remarks}

Together these analyses of two dominant mechanisms affecting Arctic coastlines, coastal erosion and storm surge flooding, suggest differential habitat responses within a relatively small but ecologically important portion of northern
Alaska. The loss of land and lake area due to increases in coastline erosion is altering the composition of habitat types and may be leading to new vegetation successional trajectories. Monitoring such vegetation and permafrost responses in both aquatic and terrestrial habitats offers an important opportunity to better understand how and to what extent wildlife populations thrive or decline in this seemingly new regime of rapid changes in shoreline position, shape, and ocean-land connectivity. The conversion of freshwater lakes to DTLBs or brackish lakes and estuaries by both coastline erosion and storm surge flooding may dramatically alter the benthic food webs and energy resources of these waterbodies, as well as the timing and duration of open-water extent during short Arctic summers. Do such changes simply provide a new composition of coastal habitat types to be exploited by different invertebrates, fishes, and avifauna, or will these biological communities be too slow in responding to locally new environment and potentially unique successional conditions? Certain types of tundra appear to be more prone to salt-burn than others and these susceptible areas appear quite patchily distributed across the Arctic coastal plains. Can such altered tundra environments still provide appropriate forage for caribou or other terrestrial mammals and birds? Do more rapidly eroding ocean and lake shorelines still provide appropriate denning habitat for polar bears, which may be increasingly forced to rely on terrestrial rather than sea ice habitats? Answering these questions will require more targeted studies of biophysical processes, as well as surface hydrologic and permafrost processes, related to the two mechanisms of habitat change addressed in this study. The N-TLSA represents a portion of the Arctic coastline that we know is responding very rapidly to changing land and ocean conditions, and thus presents a key research setting to focus on more complex ecosystemlevel responses to Arctic climate change.

Acknowledgments We thank the Bureau of Land Management, U.S. Fish and Wildlife Service, Richard Beck with University of Cincinnati, and Barrow Arctic Research Consortium for logistical and technical support and Philip Martin with U.S. Fish and Wildlife Service and 
Craig Ely with U.S. Geological Survey for helpful and thorough review of this manuscript. This manuscript was also improved by comments from two anonymous reviewers. Funding for this research was primarily provided by the U.S. Geological Survey Alaska Science Center, U.S. Geological Survey Land Remote Sensing and Geographic Analysis and Monitoring programs, and additional support was also provided by NSF.

Open Access This article is distributed under the terms of the Creative Commons Attribution Noncommercial License which permits any noncommercial use, distribution, and reproduction in any medium, provided the original author(s) and source are credited.

\section{References}

Arp C, Jones B (2009) Geography of Alaska Lake Districts: identification, description, and analysis of lake-rich regions of a diverse and dynamic state. US Geological Survey Scientific Investigations Report 2008-5215

Arp C, Jones B, Whitman M, Larsen A, Urban F (in press) Lake temperature and ice cover regimes in the Alaskan Subarctic and Arctic: integrated monitoring, remote sensing, and modeling. J Am Water Resour Assoc

Atkinson D (2005) Observed storminess patterns and trends in the circum-Arctic coastal regime. Geo-Mar Lett 25:98-109

Bentzen R, Powell A, Suydam R (2008) Factors influencing nesting success of king eiders on northern Alaska's coastal plain. J Wildl Manag 72:1781-1789

Bollinger K, Derksen D (1996) Demographic characteristics of molting black brant near Teshekpuk Lake, Alaska. J Field Ornithol 67:141-158

Brigham-Grette J, Carter L (1992) Pliocene marine transgressions of northern Alaska: circumarctic correlations and paleoclimatic interpretations. Arctic 45:74-89

Brigham-Grette J, Hopkins D (1995) Emergent marine record and paleoclimate of the last interglacation along the northwest Alaskan coast. Quat Res 43:159-173

Brown J (1968) An estimation of ground ice, coastal plain, northern Alaska. US Army Cold Regions Research and Engineering Laboratory Report

Carson C, Hussey K (1962) The oriented lakes of arctic Alaska. J Geol 70:417-439

Couture N, Pollard W (2007) Modeling geomorphic responses to climate change. Clim Chang 85:407-431

Derksen D, Eldridge W, Weller M (1982) Habitat ecology of Pacific black brant and other geese moulting near Teshekpuk Lake, Alaska. Wildfowl 33:39-57

Durner G, Douglas D, Nielson R, Amstrup S, McDonald T, Stirling I, Mauritzen M, Born E, Wilg O, DeWeaver E, Serreze M, Belikov S, Holland M, Aaras J, Bailey D, Derocher A (2009) Predicting 21 st-century polar bear habitat distribution from global climate models. Ecol Monogr 79:25-58

Fischbach A, Amstrup S, Douglas D (2007) Landward and eastward shift in Alaskan polar bear denning associated with recent sea ice changes. Polar Biol 30:1395-1405

Flint P, Mallek E, King R, Schmutz J, Bollinger K, Derksen D (2008) Changes in abundance and spatial distribution of geese molting near Teshekpuk Lake, Alaska: interspecific competition or ecological change? Polar Biol 31:549-556

Hinkel K, Eisner W, Bockheim J, Nelson F, Peterson K, Dai X (2003) Spatial extent, age, and carbon stocks in drained thaw lake basins on the Barrow Peninsula, Alaska. Arct Anarct Alp Res 35:291300
Hinzman L, Bettez N et al (2005) Evidence and implications of recent climate change in northern Alaska and other arctic regions. Clim Chang 72:251-298

Hopkins D (1967) Quaternary marine transgressions in Alaska. In: Hopkins D (ed) The Bering Land Bridge. Standford University Press, Standford, pp 47-90

Jones B, Hinkel K, Arp C, Eisner W (2008) Modern erosion rates and loss of coastal features and sites, Beaufort Sea coastline, Alaska. Arctic 61:361-372

Jones B, Arp C, Hinkel K, Beck R, Schmutz J, Winston B (2009a) Arctic lake physical processes and regimes with implications for winter water availability and management in the National Petroleum Reserve Alaska. Environ Manag 43:1071-1084

Jones B, Arp C, Jorgenson M, Hinkel K, Schmutz J, Flint P (2009b) Increase in the rate and uniformity of coastline erosion in Arctic Alaska. Geophys Res Lett 36:1-5

Jones B, Kolden C, Jandt R, Abatzoglou J, Urban F, Arp C (2009c) Fire behavior, weather, and burn severity of the 2007 Anaktuvuk River tundra fire, North Slope, Alaska. Arct Anarct Alp Res 41:309-316

Jones B, Arp C, Beck R, Grosse G, Webster J, Urban F (2009d) Erosional history of Cape Halkett and contemporary monitoring of bluff retreat, Beaufort Sea coast, Alaska. Polar Geogr 32:129-142

Jorgenson M (2000) Hierarchical organization of ecosystems at multiple spatial scales on the Yukon-Kuskokwim Delta, Alaska, USA. Arct Anarct Alp Res 32:221-239

Jorgenson M, Brown J (2005) Classification of the Alaskan Beaufort Sea Coast and estimation of carbon and sediment inputs from coastal erosion. Geo-Mar Lett 25:69-80

Jorgenson T, Ely C (2001) Topography and flooding of coastal ecosystems on the Yukon-Kuskokwim Delta, Alaska: Implications for Sea-level rise. J Coast Res 17:124-136

Jorgenson M, Shur Y (2008) Glaciation of the Coastal Plain of northern Alaska. EOS Trans 89:C11D-0554

Jorgenson M, Shur Y, Pullman E (2006) Abrupt increase in permafrost degradation in Arctic Alaska. Geophys Res Lett 33:1-4

King J, Hodges J (1979) A preliminary analysis of goose banding on Alaska's arctic slope. In: Jarvis R, Bartonek J (eds) Management and biology of pacific flyway geese. Oregon State University Bookstores, Corvallis, pp 176-188

Lawrence D, Slater A, Tomas R, Holland M, Deser C (2008) Accelerated Arctic land warming and permafrost degradation during rapid sea ice loss. Geophys Res Lett 35:1-6

Lynch A, Cassano E, Cassano J, Lestak L (2003) Case studies of high wind events in Barrow, Alaska: climatological context and development processes. Mon Weather Rev 131:719-732

Lynch A, Curry J, Brunner R, Maslanik J (2004) Toward an integrated assessment of the impact of extreme wind events on Barrow, Alaska. Am Meteorol Soc 85:209-221

Manson G, Solomon S, Forbes D, Atkinson D, Craymer M (2005) Spatial variability of factors influencing coastal change in the western Canadian Arctic. Geo-Mar Lett 25:138-145

Markon C, Derksen D (1994) Identification of tundra land cover near Teshekpuk Lake, Alaska using SPOT satellite data. Arctic 47:222-231

Mars J, Houseknecht D (2007) Quantitative remote sensing study indicates doubling of coastal erosion rate in past 50 years along a segment of the Arctic coast of Alaska. Geology 35:583-586

Mellor J (1982) Bathymetry of Alaskan Arctic lakes: a key to resource inventory with remote sensing methods. Dissertation, University of Alaska Fairbanks

Person P, Ruess R (2003) Stability of a subarctic:plant community resistance to tidal inundation. Ecoscience 10:351-360

Person B, Prichard A, Carroll G, Yokel D, Suydam R, George J (2007) Distribution and movement of the Teshekpuk Lake caribou heard, 1990-2005: prior to oil and gas development. Arctic 60:238-250 
Post E, Forschammer M, Bret-Harte M, Callaghan T, Christensen T, Elberling B, Fox A, Gilg O, Hik D, Hoye T, Ims R, Jeppesen E, Klein D, Madsen J, McGuire A, Rysgaard S, Schindler D, Stirling I, Tamstrof M, Tyler N, Rvd Wal, Welker J, Wookey P, Schmidt N, Aastrup P (2009) Ecological dynamics across the Arctic associated with recent climate change. Science 325:1355-1358

Reimnitz E, Maurer D (1979) Effects of storm surges on the Beaufort Sea coast, northern Alaska. Arctic 32:329-344

Reimnitz E, Graves S, Barnes P (1988) Beaufort Sea coastal erosion, sediment flux, shoreline evolution, and the erosional shelf profile. US Geological Survey Map I-1182G

Richter-Menge J, Overland J et al. (2008) Arctic Report Card 2008, NOAA

Ruz M, Hequette A, Hill P (1992) A model of coastal evolution in a transgressed thermokarst topography, Canadian Beaufort Sea. Mar Geol 106:251-278
Sellmann P, Brown J, Lewellen R, McKim H, Merry C (1975) The classification and geomorphic implications of thaw lakes on the Arctic coastal plain, Alaska. US Army Cold Regions Research and Engineering Laboratory Report

Smith T, Partridge S, Amstrup S, Schliebe S (2007) Post-den emergence behavior of polar bears (Ursus maritimus) in northern Alaska. Arctic 60:187-194

Stroeve J, Holland M, Meier W, Scambos T, Serreze M (2007) Arctic sea ice declines: faster than forecast. Geophys Res Lett 34:1-5

Taylor R (1981) Shoreline vegetation of the arctic Alaska coast. Arctic 34:37-41

Theiler E, Himmelstoss E, Zichichi L, Miller T (2005) Digital Shoreline Analysis System (DSAS) version 3.0: An ArcGIS extension for calculating shoreline change. Report No. 1304, US Geological Survey Open-file Report 2005-1304

Walker H (1985) Alaska. In: The world's coastline. Van Nostrand, Reinhold Co, New York, pp 1-10 